\title{
What a lucky shot! Photographic evidence for a medium-sized natural food-fall at the deep seafloor
}

\section{Heureuse surprise ! Évidence photographique de la présence d'un cadavre d'animal nectonique de taille moyenne sur le plancher océanique}

\author{
Thomas Soltwedel *, Karen von Juterzenka, Katrin Premke, Michael Klages \\ Alfred-Wegener-Institute for Polar and Marine Research, Columbusstraße, 27568 Bremerhaven, Germany
}

Received 25 February 2003; revised and accepted 12 May 2003

\begin{abstract}
Although the use of deep-sea imagery considerably increased during the last decades, reports on nekton falls to the deep seafloor are very scarce. Whereas there are a few reports describing the finding of whale carcasses in the deep north-eastern and south-eastern Pacific, descriptions of invertebrate or vertebrate food-falls at centimetre to metre scale are extremely rare. After 4 years of extensive work at a deep-sea long-term station in northern polar regions (AWI-"Hausgarten"), including large-scale visual observations with various camera systems covering some $10000 \mathrm{~m}^{2}$ of seafloor at water depths between 1250 and $5600 \mathrm{~m}$, this paper describes the first observation of a fish carcass at about $1280 \mathrm{~m}$ water depth, west off Svålbard. The fish skeleton had a total length of $36 \mathrm{~cm}$ and an approximated biomass of $0.5 \mathrm{~kg}$ wet weight. On the basis of in situ experiments, we estimated a very short residence time of this particular carcass of about $7 \mathrm{~h}$ at the bottom. The fast response of the motile deep-sea scavenger community to such events and the rapid utilisation of this kind of organic carbon supply might partly explain the extreme rarity of such an observation.
\end{abstract}

(C) 2003 Éditions scientifiques et médicales Elsevier SAS and Ifremer/CNRS/IRD. All rights reserved.

\section{Résumé}

Bien que l'utilisation de l'imagerie dans l'océan profond se soit accrue durant les dernières décennies, il est rare de trouver trace de la chute de necton sur le plancher océanique. Si quelques descriptions ont été faites de la présence de carcasses de baleines sur les fonds du Pacifique, la présence de cadavres d'invertébrés ou de vertébrés entre $1 \mathrm{~cm}$ et $1 \mathrm{~m}$ est extrêmement rare. Le suivi à long terme d'une station permanente en région arctique (AWI « Hausgarten») comprenant des observations visuelles à partir de caméras couvrant $10000 \mathrm{~m}^{2}$ de fonds océaniques entre 1250 et $5600 \mathrm{~m}$ a permis d'observer, pour la première fois, à $1280 \mathrm{~m}$ une carcasse de poisson au large de Svålbard. Le squelette avait une longueur de $36 \mathrm{~cm}$ et une biomasse approximative de $0,5 \mathrm{~kg}$ en poids sec. En se fondant sur des expériences in situ, le temps de résidence estimé de cette carcasse serait très court : environ 7 heures. La réponse rapide de la communauté nécrophage mobile à de tels événements et l'utilisation rapide de ce type de carbone organique expliquent la rareté de telles observations.

(C) 2003 Éditions scientifiques et médicales Elsevier SAS and Ifremer/CNRS/IRD. All rights reserved.

Keywords: Food-falls; Carcasses; Deep-sea; Imagery; Scavengers

Mots clés : Chute ; Carcasses ; Océan profond ; Imagerie ; Nécrophage

\section{Introduction}

Deep-sea benthic assemblages generally depend on particulate organic matter (POM) settling on the seafloor. Ex-

* Corresponding author: Fax: +49-471-4831-1776.

E-mail address: tsoltwedel@awi-bremerhaven.de (T. Soltwedel). ceptions are chemosynthetic communities around hydrothermal vents and cold seeps, and assemblages of microorganisms inhabiting the deep biosphere hundreds of meters below the seafloor. A yet undetermined fraction of POM consists of carcasses of dead invertebrates and vertebrates, covering a size range from centimetres to several metres. Whereas there are a few reports documenting whale car- 


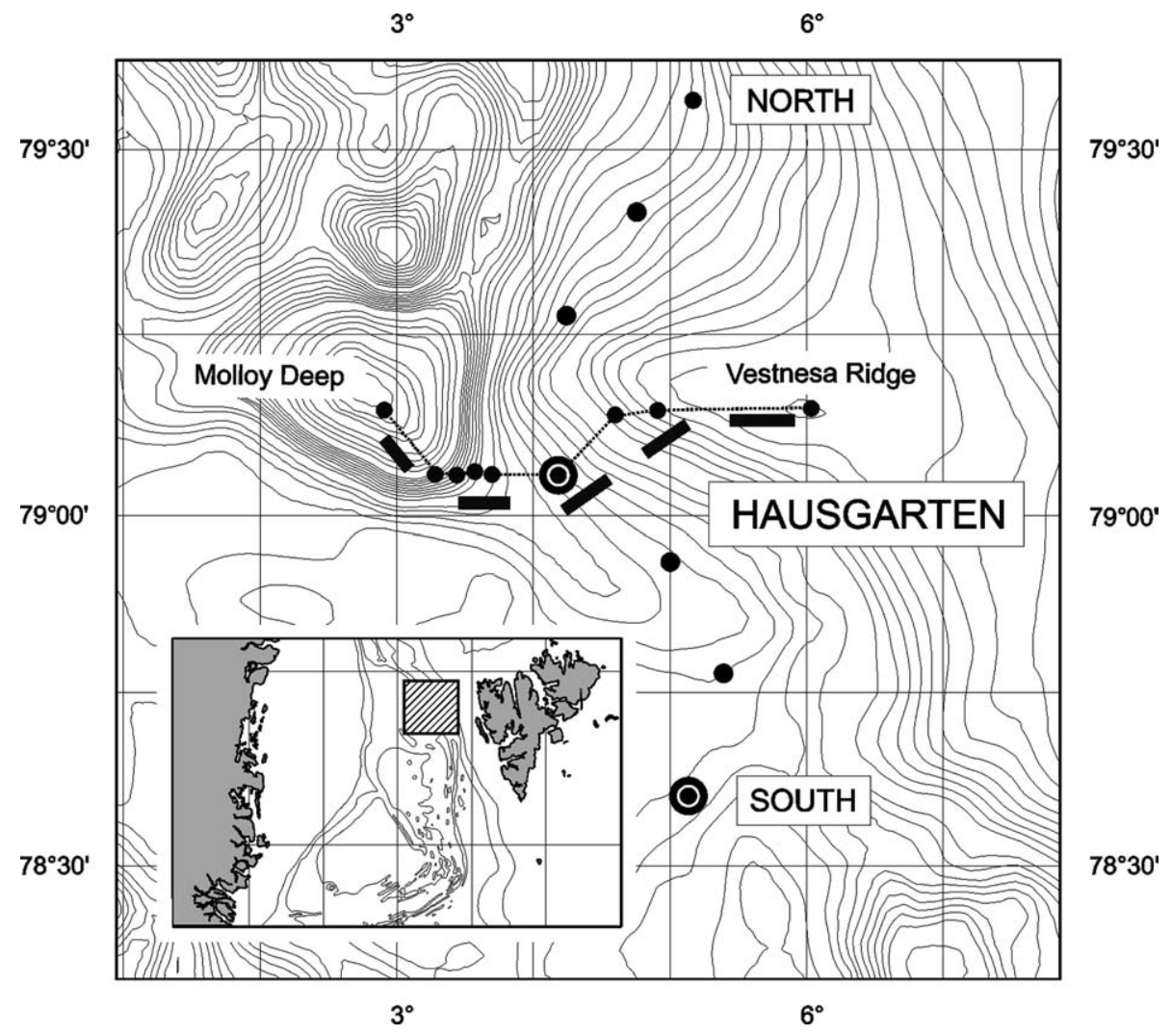

Fig. 1. The deep-sea long-term station "Hausgarten" of the Alfred-Wegener-Institute for Polar and Marine Research permanent sampling sites; Ofos transects; $\square$ : experimental areas).

casses and their fate at the deep seafloor (see Smith et al., 1998 and references therein), there is very little information on small- or medium-sized natural food-falls $(<1 \mathrm{~m})$ to be found in the literature. This short note describes the first observation of a medium-sized fish carcass at a deep-sea long-term station in northern polar regions.

\section{Methods}

In summer 1999, the German Alfred-Wegener-Institute for Polar and Marine Research (AWI) established a deep-sea long-term station (AWI-“Hausgarten") west off Svålbard (Fig. 1) to study causes and effects of physical, chemical and biological gradients in the deep sea within a multidisciplinary approach. Since then, various deep-sea systems equipped with video and still cameras were deployed to carry out visual observations, to supervise various sampling programmes, and to install experiments at the deep seafloor. An "Ocean Floor Observation System" (Ofos), a metal frame carrying a video- and 'photo-on-command' still camera, was repeatedly used to assess geological and biogenic structures, as well as epifaunal assemblages along a depth transect ranging from $1250 \mathrm{~m}$ (Vestnesa Ridge) to $5600 \mathrm{~m}$ water depth (Molloy Deep). This system was generally towed approximately $1.5 \mathrm{~m}$ above seafloor at an average towing speed of 0.5 knots. A laser scaling device consisting of three laser points at a distance of $50 \mathrm{~cm}$ enables to determine the total area covered by still camera images and to measure objects at the seafloor.

The Ofos was deployed once during RV "Polarstern" expedition ARK XIII/2 in summer 1997 at 5330-5400 m, and, recently, four times during RV "Polarstern" expedition ARK XVIII/1b in summer 2002 at 1270-1290, 1370-1660, 2360-2580 and 2830-3880 m water depth. Deployments along the AWI-"Hausgarten" transect yielded a total of $\sim 40000$ colour slides covering a distance of $17.5 \mathrm{~km}$ and an area of approximately $13500 \mathrm{~m}^{2}$. A video-guided multiple corer (MUC) was deployed for sediment sampling with prior observations of the seafloor at a vast number of sites, and several dives with a remotely operated vehicle (Rov) in summers 1999 and 2001 were used to carry out large-scale surveys and to install experiments at the seafloor. Thus, till today, some hundred hours of video observations covering water depths from 1250 to $5600 \mathrm{~m}$ and an unknown, but clearly huge area of the seafloor off Svålbard gives a comprehensive impression of the deep-sea environment at AWI"Hausgarten".

\section{Results}

By now, only one out of 40000 slides produced during Ofos deployments at AWI-"Hausgarten" (RV "Polarstern" expedition ARK XVIII/1b, Station PS62/191-1, 10 August $2002,7^{\circ} 08.8^{\prime} \mathrm{N} / 5^{\circ} 47.6^{\prime} \mathrm{E}, \sim 1280 \mathrm{~m}$ water depth) showed a 


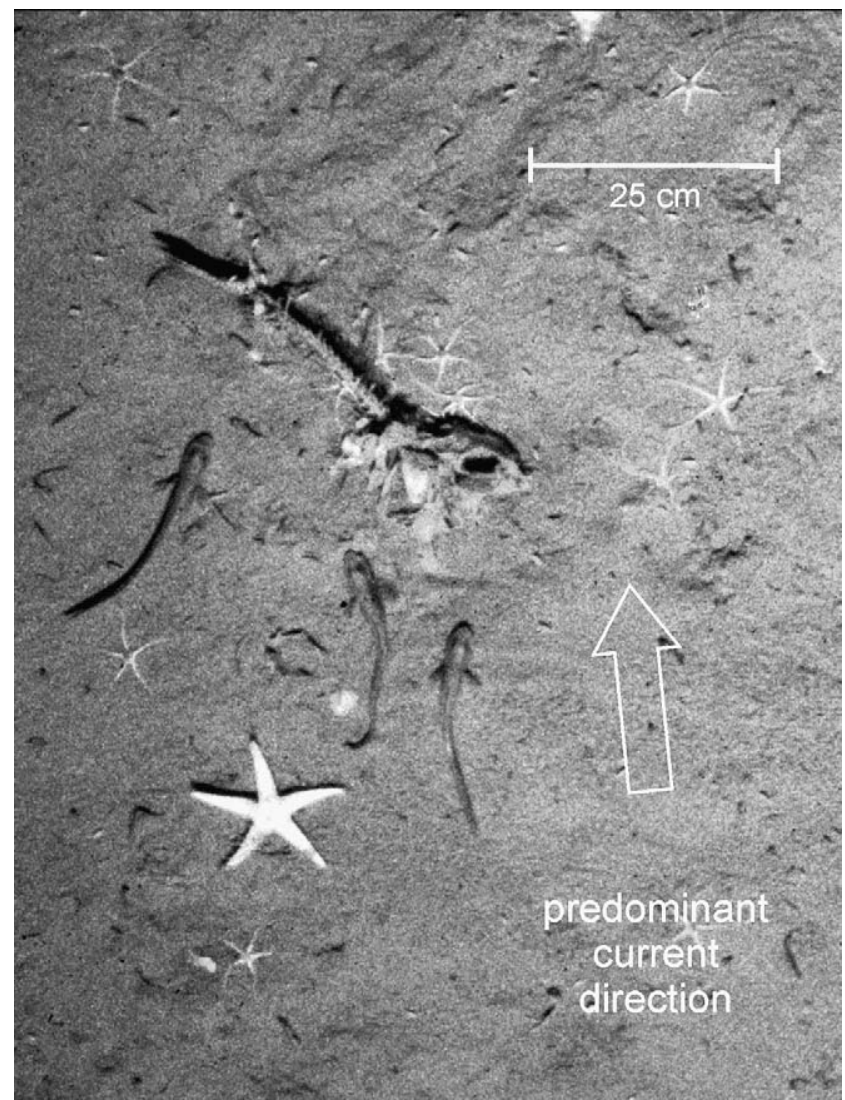

Fig. 2. Close-up of the natural food-fall (fish carcass) observed at $1280 \mathrm{~m}$ water depth west of Svålbard (7908.8' N/547.6' E).

medium-sized food-fall (Fig. 2). The skeleton identified on the slide appeared to be the remains of a $36 \mathrm{~cm}$ tall fish. Due to the relatively large skull with big eye holes, and due to the place where the picture was taken, the fish most probably belonged to the genus Sebastes (Redfish) (Stehmann, personal communication). This individual specimen must have had a biomass of approximately 450-500 g wet weight. It should be noted that the observed carcass is most likely a natural food-fall, as RV "Polarstern" definitely did not discard garbage near the Ofos track and boat traffic in the study area is almost zero.

To describe macrofauna communities directly associated with the carcass, a total of 66 seafloor images covering a distance of about $200 \mathrm{~m}$ in up-slope (25 frames) and downslope (40 frames) directions of the food-fall were analysed for abundances and distribution patterns of epifaunal organisms. Small bright organisms with a body length of approximately $1 \mathrm{~cm}$ and gammaridean-like shape were considered as amphipods. Unfortunately, the identification could not be confirmed due to the lack of sample material. Since the areas covered by single images vary slightly among each other, abundances are normalised to $10 \mathrm{~m}^{2}$.

The epibenthic macro- and mega-fauna associated with the food-fall consists mainly of ophiuroids and amphipods. Ophiuroids (Ophiocten sp., as confirmed by species identifications out of trawl samples taken in the same area) are the predominant faunal element throughout all images analysed within this study; the mean abundance was 174 ind. per $10 \mathrm{~m}^{2}$. Ophiuroid density on the slide showing the carcass (227 ind. per $10 \mathrm{~m}^{2}$ ) showed no significant difference from abundances analysed from up- or down-slope frames (Fig. 3). Nevertheless, single individuals observed on the carcass indicate that ophiuroids are obviously attracted either by the carcass itself, or by excretion products left by (other) scavengers (Fig. 2).

A different distribution pattern was observed for the organisms considered as amphipods. About 23 individuals, approximately $1 \mathrm{~cm}$ in length, were either directly attached to the carcass, or covered the surrounding seafloor within a circle of $0.5 \mathrm{~m}$ in diameter, i.e. an area of approximately $0.2 \mathrm{~m}^{2}$. Additional 21 specimens were found when increasing the circle to $1 \mathrm{~m}$ in diameter (ca. $0.8 \mathrm{~m}^{2}$ ), and further 19 individuals within a circle of $1.5 \mathrm{~m}$ in diameter. Outside this area (ca. $1.75 \mathrm{~m}^{2}$ ), amphipod densities sharply drop to about 10 ind. per $\mathrm{m}^{2}$. The entire food-fall slide exhibits a total of 85 amphipod specimens, corresponding to a calculated density of 245 ind. per $10 \mathrm{~m}^{2}$. Densities on the other slides analysed within this study range from 18 to 93 ind. per $10 \mathrm{~m}^{2}$ (mean density: 50 ind. per $\mathrm{m}^{2}$ ). The size of individuals fits within the size range of Uristes sp., which had been observed at a small food-fall in the neighbouring Molloy Deep (Klages et al., 2001).

There are three asteroids to be found close to the carcass. One specimen is apparently moving towards the carcass (there is some indication from the lifted position of one arm), two other specimen are moving in or out from different directions. On the slides analysed within this study, we observed three further asteroid specimens, but always only single individual per image. Other macrofauna elements eventually appearing along the Ofos transect are ceriantharians, gastropods, decapod crustaceans, and pycnogonids.

A total of 18 (partly juvenile?) zoarcid fishes were found evenly distributed on the slides analysed for this study, thus displaying a rather high mean density of eight specimens per $100 \mathrm{~m}^{2}$. The three 18-20 cm tall zoarcid fishes (Pachycara sp.?) to be found on the food-fall image, however, show a non-random dispersion in relation to the carcass, which could be specified from the following settings. Ofos aligns in towing direction with its ground distance weight at last. As Ofos was towed in an east-westerly direction and the predominant current direction in the study area is known to be to the north, we may conclude that the orientation of the zoarcid fishes is virtually with the currents (Fig. 2).

\section{Discussion}

Direct observations with manned submersibles and underwater photography during the last decades considerably increased our knowledge of the deep-sea realm. The finding of whale carcasses in the deep Pacific Ocean inspired various authors to investigate associated benthic assemblages and to study the fate of such large food-falls to the deep sea (Baco et al., 1996; Naganuma et al., 1996; Deming et al., 1997; Smith 


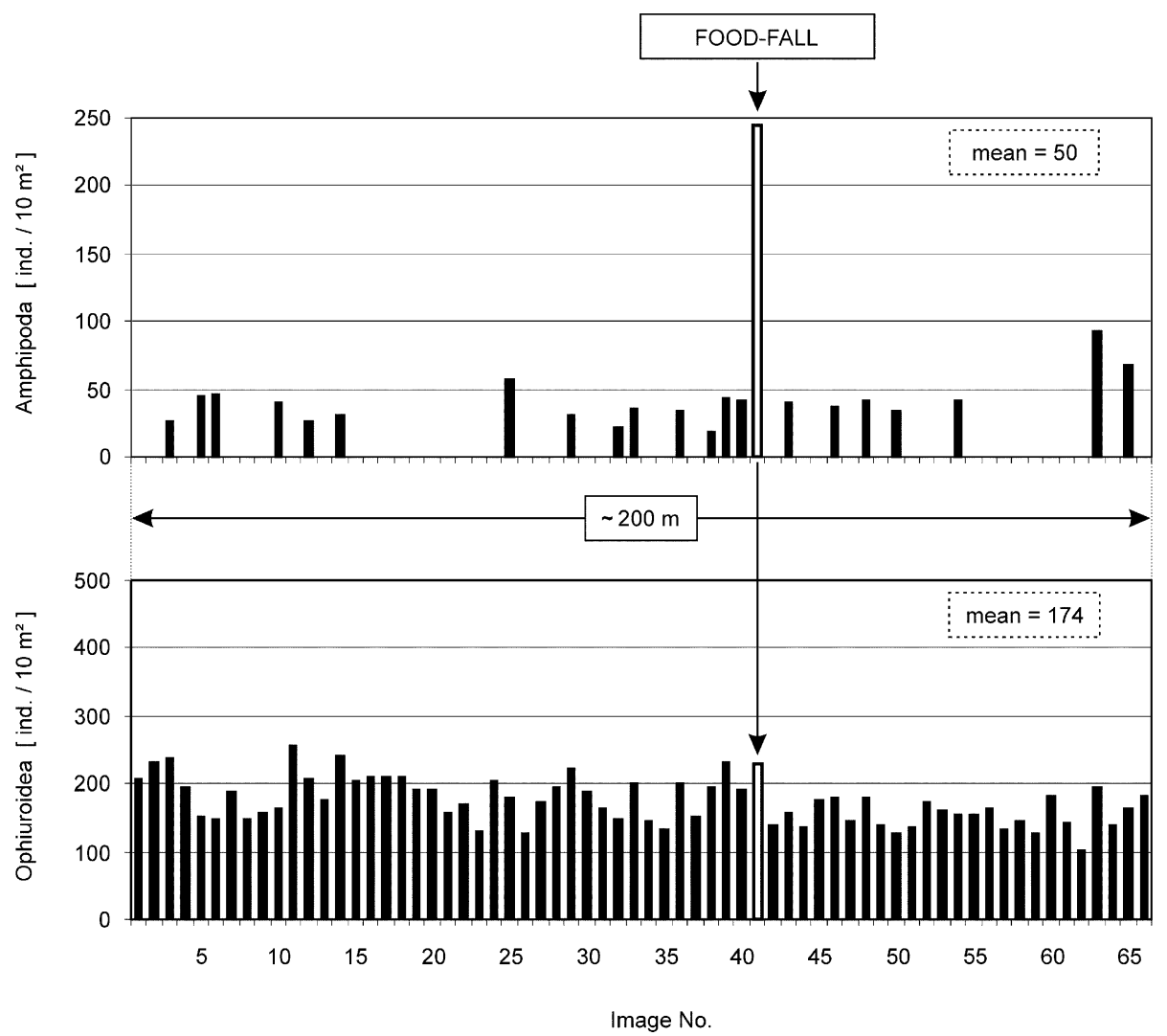

Fig. 3. Abundances and distribution patterns of amphipods and ophiuroids along the Ofos transect. White bars indicate abundances enumerated on the image (no. 41) exhibiting the fish carcass (missing bars $=$ no data).

et al., 1998). In contrast, descriptions of small- or mediumsized food-falls (centimetre to metre scale) are extremely rare (Christiansen and Boetius, 2000; Klages et al., 2001), sometimes only mentioned casually within a broader context (Heezen and Hollister, 1971; Shepard and Marshall, 1975; Jannasch, 1978; Cacchione et al., 1978; Smith, 1985), and thus hard to find in the literature. By presenting data of stomach content analyses of carnivorous deep-sea invertebrates, where food remains of dead fishes, pelagic crustaceans and pteropods were identified, Sokolova (2000) gives some indirect evidence for the occurrence of smaller foodfalls at the deep seafloor.

Klages et al. (2001) described the ongoing feeding process of scavengers on a $30 \mathrm{~cm}$ tall bathypelagic shrimp Pasiphaea tarda Krøyer, 1845, observed at $5551 \mathrm{~m}$ water depth during a ROV dive in summer 1999 in the Molloy Deep (Fram Strait), where extensive sampling and observation took place during the last 4 years. The recent finding of a fish carcass is actually the second observation of a natural food-fall within the same region, however, it is the first observation after surveying several $10000 \mathrm{~m}^{2}$ of the seafloor with Ofos-, MUC- and Rov-based still and video cameras. Whereas, the fish skeleton was found on the upper slope, the shrimp carcass (Klages et al., 2001) was observed at the bottom of the deepest depression of the Arctic Ocean (5551 m), thereby indicating that water depth, i.e. residence time in the water column, is not a decisive factor for the detection of small- or medium-sized food-falls at the deep seafloor.

There are three different hypotheses aiming to explain, why nekton food-falls are not detected in routine deep-sea bottom surveys (Stockton and DeLaca, 1982): (I) short residence times at the seafloor (i.e. rapid utilisation of food-falls by scavengers), (II) temporal variability of food-fall events (observations in the wrong season?), (III) spatial aggregation of food-falls, e.g. at sites with generally higher abundances of fish, or along migratory routes of large marine mammals (wrong place of the observer?). The latter two hypotheses cannot be tested at present, however, a number of in situ feeding experiments demonstrated that necrophages rapidly ingest and disperse carcasses efficiently within hours (e.g. Thurston, 1979; Smith, 1985; Jones et al., 1998; Janßen et al., 2000; Premke et al., 2003).

Depending on the local density of highly motile scavengers (e.g. large amphipods, fishes), the bulk of the carrion may be consumed before less motile and, hence, less competitive organisms (e.g. small amphipods, isopods, ophiuroids) can arrive and obtain their portion of the food-fall (Smith, 1985; Jones et al., 1998). Facultative scavengers might also feed on faecal pellets produced by scavengers, which already left the scene. The fact that there were mainly ophiuroids and small amphipods to be seen on the slide 
exhibiting the fish skeleton probably provides evidence for a succession of scavenging organisms as depicted above.

Ophiuroids of the genus Ophiocten, which are abundant elements of North Atlantic and Greenland Sea deep-sea communities (e.g. Piepenburg and Juterzenka, 1994; Lamont and Gage, 1998) are reported to use deposit-feeding as a main feeding mode (Pearson and Gage, 1984). Since ophiuroids are known for their versatile feeding strategies ("omnivores"), individuals observed in the vicinity of the carcass may still benefit from the leftovers. Scavenging and microphagous feeding strategies are clearly reflected by macrofauna distribution patterns observed along the Ofos transect (Fig. 3).

A comparison of epifauna densities approximately $200 \mathrm{~m}$ up- and down-slope of the carcass documented a significant aggregation of amphipods and slightly enhanced abundances of ophiuroids and asteroids and fish in the immediate vicinity of the carcass, indicating that a variety of benthic organisms is attracted by medium-sized food-falls. The three zoarcid fishes (Pachycara sp.?) attending the nekton fall most probably did not feed on the carcass, but respond to enhanced concentrations of their potential prey, i.e. the scavenging amphipods. The exploitation of scavenger aggregations by predators (fish feeding on amphipods) was observed before by the first author during feeding experiments with a Rov at the central AWI-"Hausgarten" station at 2500 m water depth in summer 1999. The zoarcid fishes attending the food-fall were oriented with the presumed currents, thereby facing at invading scavenging amphipods, attracted by the carrion odour transported in near-bottom currents.

From a feeding experiment with a baited trap at AWI"Hausgarten" in summer 2000 we may derive to a rough estimate on how long the fish carcass might have been lying at the seafloor. The trap $(20 \times 20 \times 60 \mathrm{~cm})$ was made out of Perspex $^{\mathrm{TM}}$ to allow a visual observation of activities inside the enclosure. A time-lapse camera supervising the experiment documented a large number (up to 400 individuals) of scavenging amphipods (Eurythenes gryllus) feeding on the bait, which consisted of $200 \mathrm{~g}$ of salmon filet. Nine hours after the deployment, when the bait was almost entirely eaten up by the amphipods, a $45 \mathrm{~cm}$ tall zoarcid fish calculated to have a wet weight of approximately $700 \mathrm{~g}$ entered the trap. The amphipods immediately attacked the fish, killed and finally skeletonised it within $11 \mathrm{~h}$.

The $36 \mathrm{~cm}$ tall fish carcass observed in summer 2002 was estimated to have had a biomass of 450-500 g wet weight. Assuming similar environmental conditions (e.g. comparable near-bottom currents dispersing the carrion odour) and a similar scavenger community feeding on the carcass, it would have taken about $7 \mathrm{~h}$ between touch down to the seafloor and "converting" the entire fish to what we found on that photograph. This estimate, however, is based on the assumption that the food-fall was in (fairly) good condition when reaching the seafloor. When considering already ongoing degradation and feeding on the nekton fall during passage through the water column, estimated residence time of the carcass at the seafloor would probably have been even shorter.

There is, to our knowledge, no information to be found in the literature, which might help to estimate how long a complete fish skeleton will remain as intact as the one observed on our photograph. The degradation of the fish bones by bacteria is surely a very slow process, however, the bioturbation of larger benthic organisms will probably disintegrate, disperse and bury single bones or fragments within rather short time, that is days or weeks depending on local bioturbation rates.

The frequency of nekton falls to the deep sea is still a matter of debate. The attempt made by Smith (1985), to use animal aggregations at the seafloor exceeding mean abundances in the vicinity as an indicator for food-falls, may serve as a tool for better estimates of POM flux rates to the deep seafloor via nekton falls. The increasing use of deep-sea imagery and future automations in image analysis of both, video and still photographs, will help to refine our knowledge on the importance of POM fluxes consisting of carcasses of dead invertebrates and vertebrates in the deep-sea environment.

\section{Acknowledgements}

We thank the officers and crew of RV "Polarstern" for their enthusiasms and help during expedition ARK XVIII/1b in summer 2002, and Friedhelm Kulescha (Oktopus Ltd., Germany) for technical support with the Ofos. We gratefully acknowledge Dr. Matthias Stehmann for the taxonomic classification of the fish carcass, Friederike Hoffmann for securing the ophiuroid samples and two anonymous reviewers for their valuable comments on the manuscript. This is publication "awi-n11059" of the Alfred-Wegener-Institute for Polar and Marine Research, Bremerhaven, Germany.

\section{References}

Baco, A.R., Smith, C.R., Vrijenhoek, R.C., 1996. Deep-sea whale skeleton communities on the California slope: structure, dynamics, and vent-seep affinities. EOS-Int. Newspaper Geophys. Sci. 76, 0568.

Cacchione, D.A., Rowe, G.T., Malahoff, A., 1978. Submersible investigation of Outer Hudson Submarine Canyon. In: Stanley, D.J., Kelling, G. (Eds.), Sedimentation in Submarine Canyons, Fans, and Trenches. Dowden, Hutchinson and Ross, Stroudsburg, PA, pp. 42-50.

Christiansen, B., Boetius, A., 2000. Mass sedimentation crab Charybsis smithii (Crustacea: Decapoda) in the deep Arabian Sea. Deep-Sea Res. II 47 (14), 2673-2685.

Deming, J., Reysenbach, A.L., Macko, S.A., Smith, C.R., 1997. Evidence for the microbial basis of a chemosynthetic invertebrate community at a whale fall on the deep seafloor: bone-colonizing bacteria and invertebrate endosymbionts. J. Microsc. Res. Technol. 37, 162-170.

Heezen, B.C., Hollister, C.D., 1971. The Face of the Deep. Oxford University Press, New York, pp. 659.

Jannasch, H.W., 1978. Experiments in deep-sea microbiology. Oceanus 21, $50-57$. 
Janßen, F., Treude, T., Witte, U., 2000. Scavenger assemblages under different trophic conditions: a case study in the deep Arabian Sea. Deep-Sea Res. II 47, 2999-3026.

Jones, E.G., Collins, M.A., Bagley, P.M., Addison, S., Priede, I.G., 1998 The fate of cetacean carcasses in the deep sea: observations on consumption rates and succession of scavenging species in the abyssal north-east Atlantic Ocean. Proc. R. Soc. London 265, 1119-1127.

Klages, M., Vopel, K., Bluhm, H., Brey, T., Soltwedel, T., Arntz, W.E., 2001. Deep-sea food falls: first observation of a natural event in the Arctic Ocean. Polar Biol. 24, 292-295.

Lamont, P.A., Gage, J.D., 1998. Dense brittle star population on the Scottish continental slope. Proceedings of Ninth International Echinoderm Conference, San Francisco, 1996. In: Mooi, R., Telford, M. (Eds.), Echinoderms: San Francisco. Balkema, Rotterdam, pp. 377-382.

Naganuma, T., Wada, H., Fujioka, K., 1996. Biological community and sediment fatty acids associated with the deep-sea whale skeleton at Torishima seamount. J. Oceanogr. 52, 1-15.

Pearson, M., Gage, J.D., 1984. Diets of some deep-sea brittle stars in the Rockall trough. Mar. Biol. 82 (3), 247-258.

Piepenburg, D., Juterzenka, K.V., 1994. Abundance, biomass and distribution patterns of brittle stars (Echinodermata: Ophiuroidea) on the Kolbeinsey Ridge north of Iceland. Polar Biol. 14, 185-194.
Premke, K., Muyakshin, S., Klages, M., Wegner, J., 2003. Evidence for long-range chemoreceptive tracking of food odour in deep-sea scavengers by scanning sonar data. J. Exp. Mar. Biol. Ecol. 285/286, 283-294.

Shepard, F.P., Marshall, N.F., 1975. Dives into outer Coronado Canyon System. Mar. Geol. 18, 313-323.

Smith, C.R., 1985. Food for the deep sea: utilization, dispersal, and flux of nekton falls at the Santa Catalina Basin floor. Deep-Sea Res. 32 (4), $417-442$.

Smith, C.R., Maybaum, H.J., Baco, A.R., Pope, R.H., Carpenter, S.D., Yager, P.L., Macko, S.A., Deming, J.W., 1998. Sediment community structure around a whale skeleton in the deep north-east Pacific: macrofaunal, microbial and bioturbation effects. Deep-Sea Res. II 45, 335 364.

Sokolova, M.N., 2000. Feeding and Trophic Structure of the Deep-Sea Macrobenthos. Smithsonian Institution Libraries, Amerind Publishing Co., New Delhi, pp. 264.

Stockton, W.L., DeLaca, T.E., 1982. Food falls in the deep sea: occurrence, quality, and significance. Deep-Sea Res. 29 (2A), 157-169.

Thurston, M.H., 1979. Scavenging abyssal amphipods from the north-east Atlantic Ocean. Mar. Biol. 51, 55-68. 